\title{
Effect of $\mathrm{GA}_{3}$ and Benzyladenine (BA) on Growth and Bulb Production in Lily (Lilium longiflorum)
}

\author{
Anil K. Singh, Mithilesh Kapri, Anjana Sisodia*, Minakshi Padhi and Sumit Pal \\ Department of Horticulture, Institute of Agricultural Sciences, Banaras Hindu University, \\ Varanasi-221 005, U.P., India \\ *Corresponding author
}

\section{A B S T R A C T}

In the present study, effect of $\mathrm{GA}_{3}$ and $\mathrm{BA}$ on plant growth and flowering attributes of lily was evaluated. Experiment was conducted during 2014-2015 in Horticulture Research Farm, Department of Horticulture, Institute of Agricultural Sciences, Banaras Hindu

\section{Keywords}

Lily, $\mathrm{GA}_{3}$, BA,

Growth, Bulb,

Bulblets

\section{Article Info}

Accepted:

06 May 2018

Available Online:

10 June 2018
University, Varanasi under polyhouse condition. Treatments consisted of Single and Double dose of $\mathrm{GA}_{3} 100$ ppm, $\mathrm{GA}_{3} 150$ ppm, GA 200 ppm, BA 100 ppm, BA 150 ppm, BA 200 ppm and control. The experiment was laid out in Randomized Block Design (RBD) with thirteen treatments and replicated three times. Observations were recorded on growth and bulb production lily crop. All the growth and bulb parameters were significantly influenced due to various concentrations of $\mathrm{GA}_{3}$ and $\mathrm{BA}$. Results revealed that application of Double dose of BA $150 \mathrm{ppm}$ resulted in maximum number of leaves and scales per plant. However, plants treated with Single dose of BA $100 \mathrm{ppm}$ had maximum dry weight of leaves per plant and plant height as compared to other treatments. Maximum diameter, weight of bulb and fresh weight of leaves/plant were noted with the application of Double dose of $\mathrm{GA}_{3}$ at concentration $100 \mathrm{ppm}, 150 \mathrm{ppm}$ and $200 \mathrm{ppm}$ respectively. Maximum number and weight of bulblets and diameter of bulbs were recorded with Single dose of $\mathrm{GA}_{3} 150 \mathrm{ppm}$ and $\mathrm{GA}_{3} 100 \mathrm{ppm}$ which were statistically at par with treatments BA 100 ppm (Single dose) and BA 150 ppm (Double dose).

\section{Introduction}

Lily is one of the most important bulbous flowers and commercially cultivated for cut flower production (Singh and Sisodia, 2017). A trending demand of lily (Lilium longiflorum L.) as cut flower is increasing day by day because of their showy nature of colourful spathe which has attracted medium scale cultivation. It adds instant elegance in decorations, floral arrangements, wedding bouquets and festive occasions. Being a stem rooted bulbous high value crop, it possesses a great potential for market export especially during winter. Presently, availability of quality planting materials that produces massive sized bulbs in huge number is bottleneck due to the adverse climatic condition and also affected by non-availability of micronutrients in soils of India. Growth promoting chemicals like $\mathrm{GA}_{3}$ and BA found beneficial in different flower crops (Singh, 2003 a \& b, Singh, 2005, Yadav et al., 2014, Singh et al., 2017) Application of PGR is an effortless way to 
produce more number of quality bulbs and healthy planting materials. $\mathrm{GA}_{3}$ treatment boosts the bulb and bulblet characters, cell division process, Stem and internodal elongation and vigour of various bulbous crops which was well documented by (Gu et al., 2006; Metivier and Viana, 1979). Earlier workers demonstrated that the growth of flower buds, daughter bulbs, number of leaves, fresh weight and dry weight could be induced by application of BA in low concentration (Naji et al., 2015). Hence, an attempt was made to carry out a research on application of $\mathrm{GA}_{3}$ and BA in lily cv. Novana to find out its influence on growth and bulb size.

\section{Materials and Methods}

The experiment was conducted during the year of 2014-2015 at Horticulture Research Farm, Department of Horticulture, Institute of Agricultural Sciences, Banaras Hindu University, Varanasi, India. Experiment consisted of thirteen treatments, viz., control, Single and Double dose of $\mathrm{GA}_{3} 100$ ppm, $\mathrm{GA}_{3}$ 150 ppm, GA 200 ppm, BA 100 ppm, BA $150 \mathrm{ppm}$, and BA $200 \mathrm{ppm}$ in a randomized block design (RBD) with three replications. Varanasi is situated in the Agroclimatic Zone4 (Northern transitional tract) of Uttar Pradesh State and is stretched between $82^{\circ} 56^{\prime} \mathrm{E}-83^{\circ}$ $03^{\prime} \mathrm{E}$ longitude and $25^{\circ} 14^{\prime} \mathrm{N}-25^{\circ} 23.5^{\prime} \mathrm{N}$ latitude and at altitude of $76 \mathrm{~m}$ above mean sea level.

Soil was tested on the basis of availability of essential nutrients and a homogenous piece of land under protected cultivation was selected from the composite block of Horticulture Research Farm, Department of Horticulture with adequate irrigation, tilth and proper drainage facilities. Uniformly sprouted disease free bulbs were selected for study. Bulbs treated with carbendazim were planted in a plot of size $3.0 \mathrm{~m} \times 1.5 \mathrm{~m}$ and spacing of 30 $\mathrm{cm} \times 15 \mathrm{~cm}$ on $5^{\text {th }}$ January, 2015. Foliar spray of $\mathrm{GA}_{3}$ and BA was applied after 30 and 45 days after planting. Uniform cultural practices were practised for all the treatments. Observation on growth and bulb parameters of lily plants were taken after harvesting of the crop. Plant heights in all treatments were recorded after 50, 60 and 70 days after planting. Similarly, observations on number of leaves, fresh weight, stem diameter were taken in field condition, whereas, dry weight, number and weight of bulblets, diameter and weight of bulbs were observed after harvesting of the crops. Results thus obtained were subjected to analyzed.

\section{Results and Discussion}

\section{Growth parameters}

All the growth parameters were significantly influenced due to various concentrations of $\mathrm{GA}_{3}$ and BA (Table 1). Maximum number of leaves/plant was recorded with BA $150 \mathrm{ppm}$ (Double dose) which was statistically at par with BA 200 ppm (Double dose), BA 100 ppm (Single dose and Double dose) and BA $150 \mathrm{ppm}$ (Single dose) and significant to other treatments.

Maximum fresh weight was recorded with $\mathrm{GA}_{3} 200$ ppm (Double dose). However, no significant difference was observed with BA 100 ppm (Single dose), whereas these two treatments were significant to other treatments. Application of BA 100 ppm (Single dose) resulted in maximum dry weight of leaves, plant height at 50 days and 60 days. Whereas, maximum diameter was recorded with $\mathrm{GA}_{3}$ at $100 \mathrm{ppm}$ (Double dose) which was at par with BA 100 ppm (Double dose), $\mathrm{GA}_{3} 200$ ppm (Double dose) and BA 150 ppm (Double dose). The result could be attributed to the fact that $\mathrm{GA}_{3}$ increased the plant height and stem diameter due to increase in cell division and cell enlargement. 
Table.1 The influence of $\mathrm{GA}_{3}$ and BA on growth parameters of lily

\begin{tabular}{|l|}
\multicolumn{1}{|c|}{ Treatments } \\
\hline Control \\
\hline GA $_{3} 100$ ppm (Single dose) \\
\hline GA $_{3} 100$ ppm (Double dose) \\
\hline GA $_{3} 150$ ppm (Single dose) \\
\hline GA $_{3} 150$ ppm (Double dose) \\
\hline GA $_{3} 200$ ppm (Single dose) \\
\hline GA $_{3} 200$ ppm (Double dose) \\
\hline BA 100 ppm (Single dose) \\
\hline BA 100 ppm (Double dose) \\
\hline BA 150 ppm (Single dose) \\
\hline BA 150 ppm (Double dose) \\
\hline BA 200 ppm (Single dose) \\
\hline BA 200 ppm (Double dose) \\
\hline C.D. at $5 \%$ \\
\hline
\end{tabular}

\begin{tabular}{|c|c|c|c|c|c|c|}
\hline \multirow{2}{*}{$\begin{array}{l}\text { Number of } \\
\text { leaves/plant }\end{array}$} & \multirow{2}{*}{$\begin{array}{l}\text { Fresh weight of } \\
\text { leaves/plant (g) }\end{array}$} & \multirow{2}{*}{$\begin{array}{l}\text { Dry weight of } \\
\text { leaves/plant (g) }\end{array}$} & \multirow{2}{*}{$\begin{array}{l}\text { Stem diameter } \\
(\mathbf{m m})\end{array}$} & \multicolumn{3}{|c|}{ Plant height (DAP) } \\
\hline & & & & 50 & 60 & 70 \\
\hline 63.00 & 12.33 & 1.53 & 9.45 & 31.47 & 41.83 & 56.73 \\
\hline 64.00 & 23.33 & 2.21 & 8.81 & 42.83 & 55.07 & 66.90 \\
\hline 73.00 & 21.53 & 2.17 & 10.21 & 50.63 & 65.53 & 74.20 \\
\hline 66.33 & 15.52 & 1.76 & 8.44 & 51.00 & 58.23 & 68.80 \\
\hline 72.67 & 25.56 & 2.61 & 8.20 & 50.83 & 68.53 & 78.53 \\
\hline 68.67 & 18.65 & 1.94 & 8.72 & 49.93 & 63.57 & 73.17 \\
\hline 68.33 & 29.83 & 2.88 & 9.54 & 46.93 & 59.90 & 68.87 \\
\hline 78.33 & 28.42 & 3.00 & 8.99 & 54.17 & 69.50 & 75.50 \\
\hline 77.00 & 14.67 & 1.79 & 10.06 & 52.53 & 65.80 & 73.80 \\
\hline 77.00 & 19.23 & 2.11 & 8.43 & 43.93 & 57.40 & 67.87 \\
\hline 83.67 & 15.42 & 1.94 & 9.17 & 51.13 & 65.07 & 75.10 \\
\hline 74.00 & 16.01 & 2.00 & 8.22 & 46.10 & 57.60 & 69.77 \\
\hline 82.33 & 14.59 & 1.75 & 7.69 & 43.87 & 56.63 & 66.53 \\
\hline 9.10 & 3.45 & 0.27 & 1.45 & 3.31 & 5.80 & 7.42 \\
\hline
\end{tabular}

Table.2 The influence of $\mathrm{GA}_{3}$ and BA on bulb parameters of lily

\begin{tabular}{|c|}
\hline Treatment \\
\hline Control \\
\hline $\mathrm{GA}_{3} 100$ ppm (Single dose) \\
\hline $\mathrm{GA}_{3} 100$ ppm (Double dose) \\
\hline $\mathbf{G A}_{3} 150$ ppm (Single dose) \\
\hline $\mathrm{GA}_{3} 150$ ppm (Double dose) \\
\hline $\mathrm{GA}_{3} 200$ ppm (Single dose) \\
\hline $\mathrm{GA}_{3} 200$ ppm (Double dose) \\
\hline BA 100 ppm (Single dose) \\
\hline BA 100 ppm (Double dose) \\
\hline BA 150 ppm (Single dose) \\
\hline BA 150 ppm (Double dose) \\
\hline BA 200 ppm (Single dose) \\
\hline BA 200 ppm (Double dose) \\
\hline C.D. at $5 \%$ \\
\hline
\end{tabular}

\begin{tabular}{|c|c|c|c|c|}
\hline $\begin{array}{l}\text { Weight of bulb/plant } \\
\text { (g) }\end{array}$ & $\begin{array}{l}\text { Diameter of bulb } \\
(\mathrm{mm})\end{array}$ & No. of scales/plant & $\begin{array}{l}\text { Weight of bulblets/plant } \\
\text { (g) }\end{array}$ & No. of bulblets/plant \\
\hline 9.21 & 26.39 & 7.33 & 0.23 & 3.00 \\
\hline 13.37 & 37.76 & 12.33 & 0.32 & 5.33 \\
\hline 12.23 & 24.74 & 12.67 & 0.49 & 8.33 \\
\hline 12.05 & 30.64 & 11.00 & 0.52 & 9.33 \\
\hline 16.30 & 36.35 & 12.67 & 0.28 & 5.00 \\
\hline 11.95 & 29.96 & 11.33 & 0.39 & 7.00 \\
\hline 12.04 & 32.88 & 11.33 & 0.34 & 6.33 \\
\hline 9.69 & 31.86 & 12.66 & 0.39 & 7.00 \\
\hline 11.43 & 30.14 & 10.00 & 0.32 & 6.00 \\
\hline 10.39 & 32.67 & 10.33 & 0.21 & 3.67 \\
\hline 11.71 & 32.68 & 13.67 & 0.41 & 7.33 \\
\hline 12.17 & 32.81 & 11.00 & 0.20 & 3.67 \\
\hline 10.53 & 30.36 & 10.33 & 0.25 & 4.33 \\
\hline 3.51 & 6.90 & 3.12 & 0.13 & 2.78 \\
\hline
\end{tabular}


Similar findings are also experimentally substantiated by Singh (2003b) in calendula, Singh (2005) in California poppy, Kumar et al., (2013) in tulip and Rani et al., (2015) on gladiolus. Similarly, maximum number of leaves in chamomile plant (Matricaria chamomilla) which might be due to large size corm reserves more food and supplying more storage nutrients to the leaves and other parts, that initially helps to vigorous growth and enhance to produce maximum number of leaves and maximum fresh weight/plant.

\section{Bulb parameter}

Response of $\mathrm{GA}_{3}$ and $\mathrm{BA}$ at different concentration was recorded to find out the optimum bulb yield (Table 2). Application of $\mathrm{GA}_{3} 150 \mathrm{ppm}$ (Double dose) resulted in maximum weight of bulb/plant which was statistically at par with $\mathrm{GA}_{3} 100 \mathrm{ppm}$ (Single dose) and significant to other treatments. A reverse trend was observed in case of diameter of bulb in which maximum diameter of bulb was recorded with $\mathrm{GA}_{3} 100 \mathrm{ppm}$ (Single dose) followed by $\mathrm{GA}_{3}$ ppm (Double dose). However maximum number of scales/ plant was registered with BA 150 ppm (Double dose) and minimum number of scales/plant was recorded under control. $\mathrm{GA}_{3}$ at $150 \mathrm{ppm}$ (Single dose) registered significantly higher weight and number of bulblets/plant followed by $\mathrm{GA}_{3} 100 \mathrm{ppm}$ (Double dose), BA 150 ppm (Double dose), BA 100 ppm (Single dose), $\mathrm{GA}_{3} 200$ ppm (Single dose) and $\mathrm{GA}_{3} 200 \mathrm{ppm}$ (Double dose). However, minimum weight of bulblets and number of bulblets/plant was recorded under control which was significantly lower than various $\mathrm{GA}_{3}$ and $\mathrm{BA}$ treatments. Bulb size influenced vegetative growth and all other parameters measured in lily at the time of planting. With increase in the size of bulb, parameters measured also increased in proportion to the size of the planted bulb (Addai et al., 2011). Bulbs of maximum diameter generally produced from large sized bulbs as larger ones having higher amount of food reserves that helps to vigorous growth of plant and attributed to larger bulb size with maximum weight of bulbs and bulblets which was lent credence with the observations made by Kumar et al., (2013) on tulip flower and Choudhury et al., (2010) in tuberose plant, Pogroszewska and Sadkowska (2008) on Alba (Campanula persicifolia L.) and Jamil et al., (2016) in Hippeastrum (Hippeastrum hybridum). Maximum bulblets/plants was recorded with the application of $\mathrm{GA}_{3}$ which agreed with the findings of Choudhury et al., (2010) in tuberose plant, Taha et al., (2012) on iris plant and Bose et al., (1980) in Hippeastrum.

It may be concluded that application of $\mathrm{GA}_{3}$ and BA was beneficial in improving plant growth and bulb parameters in lily. Foliar spray of $\mathrm{GA}_{3}$ significantly influenced the bulb characters while application of BA affects the growth attributes in lily plant.

\section{References}

Addai, I.K. and Scott, P. 2011. Plant carbohydrate partitioning and metabolism of lily (Lilium longiflorum L.) during bulb production. Ghana J. Hort., 9: 13-23.

Bose, T.K., Jana, B.K. and Mukhopadhyay, T.P. 1980. Effects of growth regulators on growth and flowering in Hippeastrum hybridum

Hort. Scientia Horticulturae, 12(2): 195-200.

Choudhury, S., Amin, M.R., Uddin, A.K.M. and Uddain, J. 2010. Influence of bulb size and $\mathrm{GA}_{3}$ on bulb and bulblets production of tuberose. International Journal of Bio-resource and Stress Management, 1(3): 180-183.

De Munk, W.J. 1979. Influence of plant growth regulators on the development of bulbous plants with special reference to organ relationships. Acta Hort., 91: 207-220 
Dutta, J.P. and Ramadas, S. 1998. Growth and flowering response of chrysanthemum (Dendranthema grandiflora Tzelev.) to growth regulator treatments. Orissa $J$. Hort., 26(1): 70-75.

Emongor, V.E., Mutunga, C.M.M. and Chweya, D. 2004. Effect of benzyladenine on growth and flower yield of chamomile plants. Tropical Agriculture, 81(1): 1-6.

Gul, H., A.M. Khattak, A.M. and Amin, N. 2006. Accelerating the growth of Araucaria heterophylla seedling through different $\mathrm{GA}_{3}$ concentrations and nitrogen levels. J. Agric. Biological. Sci., 1(2): 2529.

Jamil, M.K., Rahman, M.M., Hossain, M.M., Hossain, M.T., and Karim, A.S. 2016. Effect of plant growth regulators on flower and bulb production of Hippeastrum hybridum. Bangladesh Journal of Agricultural Research,40(4): 591-600.

Kumar, R., Ahmed, N., Singh, B.R., Sharma, O.C., Lal, S. and Salmani, M.M. 2013. Enhancing blooming period and propagation coefficient of tulip (Tulipa gesneriana L.) using growth regulators. African Journal of Biotechnology, 12(2): 168-74.

Naji, D.A., Attiya, H.J. and Askar, H.M. 2015. Effect of plant growth regulators (iba, ba, and ccc) on some vegetative characters of three hybrid lily cultivars of (Lilium spp. L.). Iraqi Journal of Science, 56(2): 972982

Pogroszewska, E. and Sadkowska, P. 2008. The effect of benzyladenine on the flowering of Campanula persicifolia. 'Alba' cultivated in an unheated plastic tunnel and in the field. Acta Sci. Pol. Hortorum Cultus., 7(3): 57-63.
Rani, P., Yadav, K., Kataria, N., Singh, N., Hussain D.M. and Groach, R. 2015. Assessment of growth, floral and yield attributes of gladiolus in response to gibberellic acid treatment. Botany Research International, 8(1): 01-06.

Singh, A.K. 2003a. Effect of plant bioregulators on growth, biomass and flowering in French marigold (Tagetes patula). Indian Perfumer, 46(3): 279-282.

Singh, A.K. 2003b. Effect of growth regulators on growth and flowering in calendula (Calendula officinalis). Indian Perfumer, 46(3): 275-278.

Singh, A.K. 2005. Growth and seed yield in California poppy (Eschsholtzia californica Chamisso) as influenced by plant growth regulators. J. Ornamental Horticulture, 8(2): 159-160.

Singh, A.K. and Bijimol, G. 2001. Influence of growth regulating chemicals on growth, flowering and bulb production in tuberose (Polianthes tuberosa L.). Indian Perfumer, 45(1): 31-34.

Singh, A.K. and Sisodia, Anjana. 2017. Textbook of Floriculture and Landscaping, New India Publishing Agency, New Delhi. pp. 432.

Singh, A.K., Kumar, P., Sisodia, A., Pal, A.K., Singh, H.V. and Padhi, Minakshi. 2017. Effect of pinching, urea and $\mathrm{GA}_{3}$ on growth, flowering and seed attributes in African marigold (Tagetes erecta L.). J. Ornamental Horticulture, 20(1\&2): 3439.

Yadav, K.S., Sisodia, A. and Singh, A.K. 2014. Effect of $\mathrm{GA}_{3}$ and kinetin on growth and flowering parameters of African marigold (Tagetes erecta). Indian Perfumer, 58(1): 21-25.

\section{How to cite this article:}

Anil K. Singh, Mithilesh Kapri, Anjana Sisodia, Minakshi Padhi and Sumit Pal. 2018. Effect of $\mathrm{GA}_{3}$ and Benzyladenine (BA) on Growth and Bulb Production in Lily (Lilium longiflorum). Int.J.Curr.Microbiol.App.Sci. 7(06): 1236-1240. doi: https://doi.org/10.20546/ijcmas.2018.706.145 